\title{
Activity of [Des-Aspartyl ${ }^{1}$ ]-Angiotensin II and Angiotensin II in Man
}

\author{
DIFFERENCES IN BLOOD PRESSURE AND ADRENOCORTICAL RESPONSES \\ DURING NORMAL AND LOW SODIUM INTAKE
}

\author{
Robert M. Carey, E. Darracott Vaughan, Jr., Michael J. Peach, and \\ CARLOS R. AYERS, The Departments of Internal Medicine, Urology, and \\ Pharmacology, University of Virginia School of Medicine, Charlottesville, \\ Virginia 22901
}

\begin{abstract}
A B S T RACT This study was designed to compare the effect of [des-Aspartyl ${ }^{1}$ ]-angiotensin II ([des-Asp]A II) and angiotensin II (A II) on blood pressure and aldosterone production in man under conditions of normal and low sodium ( $\mathrm{Na}$ ) intake. Seven normal male subjects in balance on constant normal $\mathrm{Na}$ intake $\left(\mathrm{U}_{\mathrm{Na}} \mathrm{V}\right.$ $160.3 \pm 5.0 \mathrm{meq} / 24 \mathrm{~h}$ ) for 5 days received A II and [desAsp]-A II infusions on two consecutive days; 1 mo later they were restudied after 5 days of low $\mathrm{Na}$ intake $\left(\mathrm{U}_{\mathrm{Na}} \mathrm{V}\right.$ $10.5 \pm 1.6 \mathrm{meq} / 24 \mathrm{~h}$ ). Each dose was infused for $30 \mathrm{~min}$, sequentially. During normal Na intake, [des-Asp]-A II from 2 to $18 \mathrm{pmol} / \mathrm{kg}$ per min increased mean blood pressure from $85.2 \pm 3$ to $95.3 \pm 5 \mathrm{~mm} \mathrm{Hg}$ and plasma aldosterone concentration from $5.2 \pm 1.1$ to $14.3 \pm 1.9 \mathrm{ng} /$ $100 \mathrm{ml}$. During low Na intake, the same dose of [desAsp]-A II increased mean blood pressure from 83.7 \pm 3 to $86.7 \pm 3 \mathrm{~mm} \mathrm{Hg}$ and plasma aldosterone concentration from $34.4 \pm 6.0$ to $51.0 \pm 8.2 \mathrm{ng} / 100 \mathrm{ml}$. In contrast, A II from 2 to $6 \mathrm{pmol} / \mathrm{kg}$ per min during normal $\mathrm{Na}$ intake increased mean blood pressure from $83.3 \pm 4$ to $102.3 \pm 4 \mathrm{~mm} \mathrm{Hg}$ and plasma aldosterone concentration from $7.0 \pm 2.2$ to $26.8 \pm 2.0 \mathrm{ng} / 100 \mathrm{ml}$; during low $\mathrm{Na}$ intake, A II increased mean blood pressure from 83.0 \pm 3 to $96.0 \pm 4 \mathrm{~mm} \mathrm{Hg}$ and plasma aldosterone concentration from $42.0 \pm 9.7$ to $102.2 \pm 15.4 \mathrm{ng} / 100 \mathrm{ml}$. A II and [des-Asp]-A II were equally effective in suppressing renin release. Plasma cortisol and $\mathrm{Na}$ and $\mathrm{K}$ concentrations did not change.
\end{abstract}

Dr. Carey is an Established Investigator of the American Heart Association. Doctors Vaughan and Peach are recipients of U. S. Public Health Service Research Career Development Awards. Dr. Ayers is a Virginia Heart Association Professor of Cardiovascular Research.

Received for publication 3 June 1977 and in revised form 12 August 1977.
The effects of two doses ( 2 and $6 \mathrm{pmol} / \mathrm{kg}$ per min) of each peptide on blood pressure and aldosterone production were evaluated. During normal Na intake, [desAsp]-A II had 11-36\% of the pressor activity and 15$30 \%$ of the steroidogenic activity of A II. Na deprivation attenuated the pressor response and sensitized the adrenal cortex to both peptides, but the increase in steroidogenesis was greater with [des-Asp]-A II than with A II. The dose-response curves for [des-Asp]-A II with respect to blood pressure and aldosterone production were not parallel, and although no maximum was established for A II, [des-Asp]-A II was less efficacious.

In summary, $(a)$ [des-Asp]-A II has biologic activity in man, (b) [des-Asp]-A II is less efficacious than A II in stimulating aldosterone production, $(c) \mathrm{Na}$ deprivation sensitizes the adrenal cortex more markedly to [desAsp]-A II than A II, and (d) dose-response curves for the two peptides differ, suggesting the possibility that they act at different receptor sites in vascular smooth muscle and the adrenal cortex.

\section{INTRODUCTION}

In the years after the studies of Laragh $(1,2)$ demonstrating that angiotensin II (A II) ${ }^{1}$ is a potent stimulator of aldosterone secretion in man, the renin-angiotensinaldosterone cascade has become accepted as a coordinated system acting simultaneously to control blood pressure and sodium and potassium balance (3). A II is degraded into supposedly inactive fragments by the action of aminopeptidases, endopeptidases, and carboxypeptidases (4). Recently, however, the C-terminal hep-

\footnotetext{
${ }^{1}$ Abbreviations used in this paper: A II, angiotensin II; [des-Asp]-A II, [des-Aspartyl']-angiotensin II; BSA, bovine serum albumin.
} 
tapeptide fragment of A II, [des-Aspartyl ${ }^{1}$ ]-angiotensin II ([des-Asp]-A II) was found to be an agonist in that it has strong affinity for adrenal cortical receptors and stimulates aldosterone biosynthesis in vivo in the sheep (5), rat (6), rabbit (7), and dog (8) and in vitro in the rat, rabbit, cat, and $\operatorname{dog}(9,10)$. On a molar basis, [des-Asp]-A II is as potent a steroidogenic agent in these species as A II. In addition, [des-Asp]-A II possesses approximately $15-25 \%$ of the pressor activity of A II $(11,12)$ and essentially equivalent ability to suppress renin release from the kidney (13). For these reasons, [des-Asp]-A II has been designated as "angiotensin III," a putative hormone of the renin-angiotensin system. This heptapeptide, [des-Asp]-A II, has been isolated and quantified from plasma of several species $(14,15)$.

Restriction of dietary sodium intake decreases the pressor response and increases the sensitivity of the adrenal zona glomerulosa to A II and [des-Asp]-A II (16). Recent studies have shown that adrenal cells from sodium-restricted rats increase maximal aldosterone production by $45 \%$ above cells from animals on normal sodium intake in response to either A II or [des-Asp]-A II. However, the increase in adrenal zona glomerulosa sensitivity to [des-Asp]-A II during sodium depletion is 10-fold greater than for A II (16). This observation suggests that [des-Asp]-A II may mediate (at least in part) the enhanced response of the adrenal zona glomerulosa to sodium depletion.

To date, in vitro data have been consistent with an action of A II and [des-Asp]-A II at the same receptor sites in the zona glomerulosa (17-19). However, a recent study (20) utilizing the rat uterus has shown nonparallel dose-response curves for A II and [des-Asp]-A II with [des-Asp]-A II displaying lower maximum efficacy. This suggests that the two peptides may act via different receptors.

The present study was undertaken to examine the effect of [des-Asp]-A II on blood pressure and aldosterone production in man. The study was designed to answer the following questions: $(a)$ What is the effect of sodium deprivation on the pressor and steroidogenic responses to [des-Asp]-A II? (b), Do the dose-response curves of A II and [des-Asp]-A II differ from each other? To answer these questions, A II and [des-Asp]-A II were infused into normal male subjects maintained on normal and low dietary sodium.

\section{METHODS}

Human subjects and study protocol. Seven normal white male volunteer subjects, 24-30 yr, with normal arterial blood pressures and no history of renal disease were studied. The subjects were given a constant diet containing $150 \mathrm{meq}$ of sodium, $60 \mathrm{meq}$ of potassium, $1 \mathrm{~g}$ of protein $/ \mathrm{kg}$, and $2,860 \mathrm{calo}-$ ries/day for 5 days at the Clinical Research Center before the study. Consecutive 24-h urine samples were collected for the first 4 days of the diet and consecutive 12-h urine samples were collected for the remainder of each study and were analyzed for sodium, potassium, and creatinine. No food was given after midnight before study day 1 when the subjects assumed the supine position until completion of the study. At 6:15 a.m. on study day 1, the subjects completed their 12-h urine collections without arising. A heparin lock for obtaining blood samples was placed in the left antecubital vein and an intravenous infusion of $5 \%$ dextrose in water $\left(D_{5} W\right)$ at $1 \mathrm{ml} / \mathrm{min}$ was begun in the right antecubital vein. At 6:30 a.m., blood pressure monitoring with an Arteriosonde (Medical Electronics Division, Hoffman- LaRoche Inc., Cranbury, N. J.) was begun and was continued every 2 min until completion of the study. At 7:00 and 7:30 a.m., control blood samples were obtained for the determination of plasma sodium, potassium, cortisol, and aldosterone. After completion of blood sampling at 0730 hours, an intravenous infusion of [des-Asp]-A II at either 2,4 , or $6 \mathrm{pmol} /$ $\mathrm{kg}$ per min was begun. Thereafter, blood sampling was accomplished at 15-min intervals until completion of each study at 9:00 a.m. The heptapeptide, [des-Asp]-A II, was infused at three successively increasing dose levels ranging from 2 to $18 \mathrm{pmol} / \mathrm{kg}$ per min and maintained for $30 \mathrm{~min}$ at each dose level. The total duration of infusion for each subject was 90 min; blood samples for the estimation of plasma renin activity also were obtained at 0 and $90 \mathrm{~min}$ of infusion.

After completion of the infusion at 9:00 a.m., the subjects continued on the constant diet and 12-h urine collections. On study day 2 , an identical protocol as for study day 1 was followed except that instead of [des-Asp]-A II, A II at 2, 4, and 6 $\mathrm{pmol} / \mathrm{kg}$ per min (30 min at each dose level) was administered. The diet was discontinued, and the subjects were discharged from the Clinical Research Center after completion of the final 12-h urine collection at 6:30 p.m. on study day 2 . The total volume of blood obtained from each subject during the two study days was $220 \mathrm{ml}$.

After an interval of $4 \mathrm{wk}$ on an ad lib. diet, the same subjects were placed on a constant diet containing $10 \mathrm{meq}$ of sodium, $60 \mathrm{meq}$ of potassium, $1 \mathrm{mg}$ of protein $/ \mathrm{kg}$, and 2,860 calories/day for 5 days at the Clinical Research Center before study. After sodium balance had been achieved, an identical protocol was carried out again at the Clinical Research Center with infusion of the same dose levels of [des-Asp]-A II and A II on the two consecutive study days.

Before and during angiotensin peptide infusions, blood pressure was monitored with an Arteriosonde automatic ultrasonic blood pressure recorder. A blood pressure cuff (with a width approximately two-thirds the width of the arm and a length such that the bladder completely encircled the arm) was wrapped snugly around the left arm. The Arteriosonde was calibrated daily against a random-zero mercury sphygmomanometer. Control blood pressures are expressed as the mean of 15 readings between -60 and -30 $\min (6: 30-7: 00$ a.m.) and between -30 to $0 \mathrm{~min}$ (7:00$7: 30$ a.m. = zero control value) before initiation of the peptide infusions. During peptide infusions, blood pressure is expressed as the mean of seven readings for each 15-min period from 0 to $90 \mathrm{~min}$ of infusions (7:30-9:00 a.m.). The change in blood pressure is the difference between the zero control value and each 15-min infusion period. Written informed consent for these studies was obtained from all subjects. If the mean blood pressure increase during any peptide infusion was $20 \mathrm{~mm} \mathrm{Hg}$, the infusion was terminated.

Synthetic [des-Asp, Ile ${ }^{5}$ ]-A II was provided by Beckman Instruments, Inc., Fullerton, Calif. Synthetic [Asn $\left.{ }^{1}, \mathrm{Val}^{5}\right]-\mathrm{A}$ II (Hypertensin, Ciba) was purchased from Ciba Pharmaceutical Co., Div. CIBA-GEIGY Corp., Summit, N. J. Previous studies have shown no differences between val ${ }^{5}$ and ile $^{5}$ analogues of [des-Asp]-A II and A II with respect to blood pressure, adrenal cortical aldosterone production, or 
binding to adrenal cortical cells $(5,6,12,17)$. The [Asn ${ }^{1}$, $\mathrm{Val}^{5}$ ]-A II was not contaminated with [des-Asp]-A II as demonstrated by thin-layer chromatography in a system of butanol, acetic acid, water, and puridine. These peptides were diluted in sterile $\mathrm{H}_{2} \mathrm{O}$, filtered with $0.22-\mu \mathrm{m}$ millipore filter (Millipore Corp., Bedford, Mass.), and stored at $4^{\circ} \mathrm{C}$ in sterile vials for $1-6 \mathrm{wk}$ at a concentration of $50 \mu \mathrm{g} / \mathrm{ml}$.

Animal in vivo and in vitro studies. Random aliquots of the sterilized preparations of the peptides infused into man were assayed subsequently for pressor activity in the anesthetized rat and steroidogenesis in adrenal cortical cell suspensions from rabbits and rats.

Male Wistar rats (200-300 g) were housed individually in metabolic cages in a temperature-controlled room (20$22^{\circ} \mathrm{C}$ ) illuminated between 8 a.m. and 8 p.m. and were maintained on low sodium rat chow (General Biochemicals, Grand Island Biologicals, Chagrin Falls, Ohio) and $0.5 \%$ saline solution ad lib. to insure normal sodium intake.

A group of rats on normal sodium diet were anesthetized with intraperitoneal pentobarbital sodium $(60 \mathrm{mg} / \mathrm{kg})$. The iliac artery and femoral vein were cannulated with PE-50 intramedic tubing. A bilateral nephrectomy was performed, and the animals were allowed a 3- to 4-h equilibration period so that endogenous levels of renin and angiotensin were as low as possible without risking postnephrectomy changes in vascular reactivity. Arterial blood pressures were monitored through the arterial cannula via a Statham P23D pressure transducer (Statham Instruments Div. Gould Inc., Oxnard, Calif.) connected to a Brush Mark 220 recorder (Instrument Systems Division, Gould Inc., Cleveland, Ohio). Peptides were administered via the femoral vein in a $10-\mu l$ vol of $5 \%$ dextrose in water and flushed with $20 \mu$ l of $5 \%$ dextrose in water. A II, [des-Asp]-A II (Schwarz/Mann Div. Becton, Dickinson \& Co., Orangeburg, N. Y.), sterilized [des-Asp]-A II (Beckman Instruments), and vehicle were administered in random order.

10 rats per group (five groups) were decapitated, and the adrenal glands removed rapidly. The medulla and inner cortex were removed from each gland, and the cells of the capsular layers were dispersed. The capsular tissue was minced and incubated in Krebs-Ringer bicarbonate buffer containing $0.2 \% \mathrm{D}$-glucose, $0.025 \%$ trypsin, $4 \%$ bovine serum albumin (BSA), and $0.005 \%$ deoxyribonuclease ( $1 \mathrm{ml}$ buffer $/ 20$ $\mathrm{mg}$ tissue wet wt). After incubation for $15 \mathrm{~min}$ in a Dubnoff metabolic shaker under an atmosphere of $95 \% \mathrm{O}_{2}-5 \% \mathrm{CO}_{2}$ at $60 \mathrm{rpm}$, the tissue was washed twice with Krebs-Ringer bicarbonate buffer containing $0.05 \%$ trypsin inhibitor, $0.2 \%$ D-glucose, $0.005 \%$ deoxyribonuclease, and $4 \%$ BSA $(0.5$ $\mathrm{ml} / 20 \mathrm{mg}$ tissue). Next, the tissue was dissociated by incubation in Krebs-Ringer bicarbonate buffer with $0.2 \% \mathrm{D}$-glucose, $0.02 \%$ collagenase, $0.05 \%$ trypsin inhibitor, $4 \% \mathrm{BSA}$, and $0.005 \%$ deoxyribonuclease $(0.5 \mathrm{ml} \mathrm{buffer} / 20 \mathrm{mg}$ tissue $)$ for $20 \mathrm{~min}$ in a Dubnoff metabolic shaker (10 rpm) under a $95 \% \mathrm{O}_{2}-5 \% \quad \mathrm{CO}_{2}$ atmosphere. The enzyme-treated tissue was dispersed by pipetting. The preparation was then incubated for $10 \mathrm{~min}$, and the suspension was filtered through $150 \mu^{2}$ nylon mesh. The filtrate was centrifuged, and the pellet was washed three times and resuspended in KrebsRinger bicarbonate buffer with $0.2 \%$ D-glucose and $4 \%$ BSA. The number of viable cells present in the suspension was determined by exclusion staining with nigrosin and counting, using a Neubauer hemocytometer.

The cell suspensions were preincubated in the Dubnoff metabolic shaker for $30 \mathrm{~min}$ at $37^{\circ} \mathrm{C}$ in an atmosphere of $95 \% \mathrm{O}_{2}-5 \% \mathrm{CO}_{2}$. All compounds were added to a $10-\mu \mathrm{l}$ vol, and $10 \mu \mathrm{l}$ of vehicle was administered to control. Incubations lasting $60 \mathrm{~min}$ were used to determine dosedependent steroidogenic responses.
The adrenal glands of male New Zealand white rabbits $(2-3 \mathrm{~kg})$ that were killed by cervical dislocation also were used to prepare capsular adrenal zona glomerulosa cell suspensions in an identical manner as used for rat suspensions.

The incubations were terminated by adding $2 \mathrm{ml}$ of $99 \%$ acetone to the experimental samples. The supernatant fraction was decanted and retained, and the pellet was resuspended in $80 \%$ acetone and centrifuged. The two supernatant fractions were pooled and evaporated to aqueous phase under a stream of $\mathrm{N}_{2}$ at $40^{\circ} \mathrm{C}$. Aldosterone was purified by extraction into dichloromethane and by Sephadex (Pharmacia Fine Chemicals, Piscataway, N. J.) LH-20 column chromatography and was estimated by radioimmunoassay.

Analytical methods. All blood samples were collected on ice, centrifuged immediately, and the plasma was separated and frozen until the time for assay. Samples for plasma renin activity and aldosterone utilized EDTA as the anticoagulant; heparin was used in the samples for cortisol.

Plasma sodium and potassium were measured by flame photometry (model 143, Instrumentation Laboratory, Inc., Lexington, Mass.). Aldosterone was measured by the radioimmunoassay method of Bühler et al. (21). After incubation, plasma renin activity was determined by radioimmunoassay of angiotensin I generated as described by Sealey et al. (22). Plasma cortisol was measured by the fluorometric method of Mattingly (23).

Statistical analysis. The results are expressed as mean \pm 1 SE. Statistical analysis was carried out with the doubletailed Student's $t$ test for paired data, and $P$ values of $<0.05$ are considered significant.

\section{RESULTS}

\section{[des-Asp]-A II and A II infusion studies in man}

Characteristics of subjects on normal and low sodium intake. The characteristics of the subjects in sodium balance on the fifth day of normal ( 150 $\mathrm{meq} / \mathrm{day})$ and low (10 meq/day) sodium intake are summarized in Table I. Sodium restriction with iso-

TABLE I

Characteristics of the Subjects on Normal and Low Sodium Intake on the 5th Day of Constant Sodium Diet

\begin{tabular}{|c|c|c|c|}
\hline & \multicolumn{2}{|c|}{ Sodium intake/ $24 \mathrm{~h}$} & \multirow[b]{2}{*}{$P$ value } \\
\hline & $150 \mathrm{meq}$ & $10 \mathrm{meq}$ & \\
\hline $\begin{array}{l}\text { Weight, } k g \\
24 \text { h urinary sodium, }\end{array}$ & $75.5 \pm 2.2$ & $75.3 \pm 1.8$ & NS \\
\hline $\begin{array}{l}\text { meq } \\
24 \mathrm{~h} \text { urinary potas- }\end{array}$ & $160.3 \pm 5.0$ & $10.5 \pm 2.5$ & $<0.000001$ \\
\hline sium, meq & $61.4 \pm 1.9$ & $59.0 \pm 2.5$ & NS \\
\hline $\begin{array}{l}\text { Serum sodium, } \\
\text { meq/liter }\end{array}$ & $152.3 \pm 2.1$ & $153.3 \pm 3.1$ & NS \\
\hline $\begin{array}{l}\text { Blood pressure, } \\
m m \mathrm{Hg}\end{array}$ & & & \\
\hline Systolic & $109.6 \pm 4.1$ & $105.2 \pm 3.6$ & NS \\
\hline Diastolic & $73.4 \pm 3.1$ & $73.0 \pm 2.1$ & NS \\
\hline $\begin{array}{l}\text { Plasma renin activ- } \\
\text { ity, } n g / m l / h\end{array}$ & $1.84 \pm .22$ & $8.22 \pm 1.20$ & $<0.001$ \\
\hline $\begin{array}{l}\text { Plasma aldosterone, } \\
n g / 100 \mathrm{ml}\end{array}$ & $5.3 \pm 1.2$ & $34.4 \pm 6.6$ & $<0.005$ \\
\hline
\end{tabular}


caloric intake was not associated with significant weight reduction. On each diet, 24-h urinary sodium output closely matched intake, and 24-h urinary potassium excretion was unchanged in the presence of a constant $60-\mathrm{meq} /$ day potassium intake. In the process of achieving sodium balance on the low sodium intake, the subjects acquired a cumulative sodium deficit of $187 \pm 15$ meq. Serum sodium and potassium concentrations were unchanged by dietary sodium intake. Systolic blood pressure tended to be slightly lower when the subjects were on low sodium intake. Restriction of dietary sodium intake was associated with a highly significant increase in plasma renin activity and aldosterone concentration $(P<0.001$ and $P<0.005$, respectively). A 4.5-fold rise in plasma renin activity was associated with a 6.5 -fold increase in plasma aldosterone concentration.
Responses to [des-Asp]-A II infusion during normal sodium intake (Fig. 1). The [des-Asp]-A II infusion was associated with a series of reproducible responses. In the first $30 \mathrm{~min}$ of the control period, blood pressure was $111.0 \pm 4.5 \mathrm{~mm} \mathrm{Hg}$ systolic and $72.4 \pm 2.6$ $\mathrm{mm} \mathrm{Hg}$ diastolic and was unchanged in the second $30 \mathrm{~min}$ of the control period, $109.6 \pm 4.1 \mathrm{~mm} \mathrm{Hg}$ systolic and $73.4 \pm 3.1 \mathrm{~mm} \mathrm{Hg}$ diastolic. [des-Asp]-A II infusion resulted in a rise in systolic blood pressure to 116.7 $\pm 3.9 \mathrm{~mm} \mathrm{Hg}(P<0.02)$ within $15 \mathrm{~min}$ at $2 \mathrm{pmol} / \mathrm{kg}$ per min. However, further increase in the dose of [des-Asp]-A II to 6,12 , and $18 \mathrm{pmol} / \mathrm{kg}$ per $\mathrm{min} \mathrm{did}$ not result in a statistically significant increase in systolic blood pressure from the initial $(2 \mathrm{pmol} / \mathrm{kg}$ per min) dose. Diastolic blood pressure also increased to $76.7 \pm 3.0 \mathrm{~mm} \mathrm{Hg}$ at $15 \mathrm{~min}$ of infusion, but did not achieve statistical significance until the dose was in-

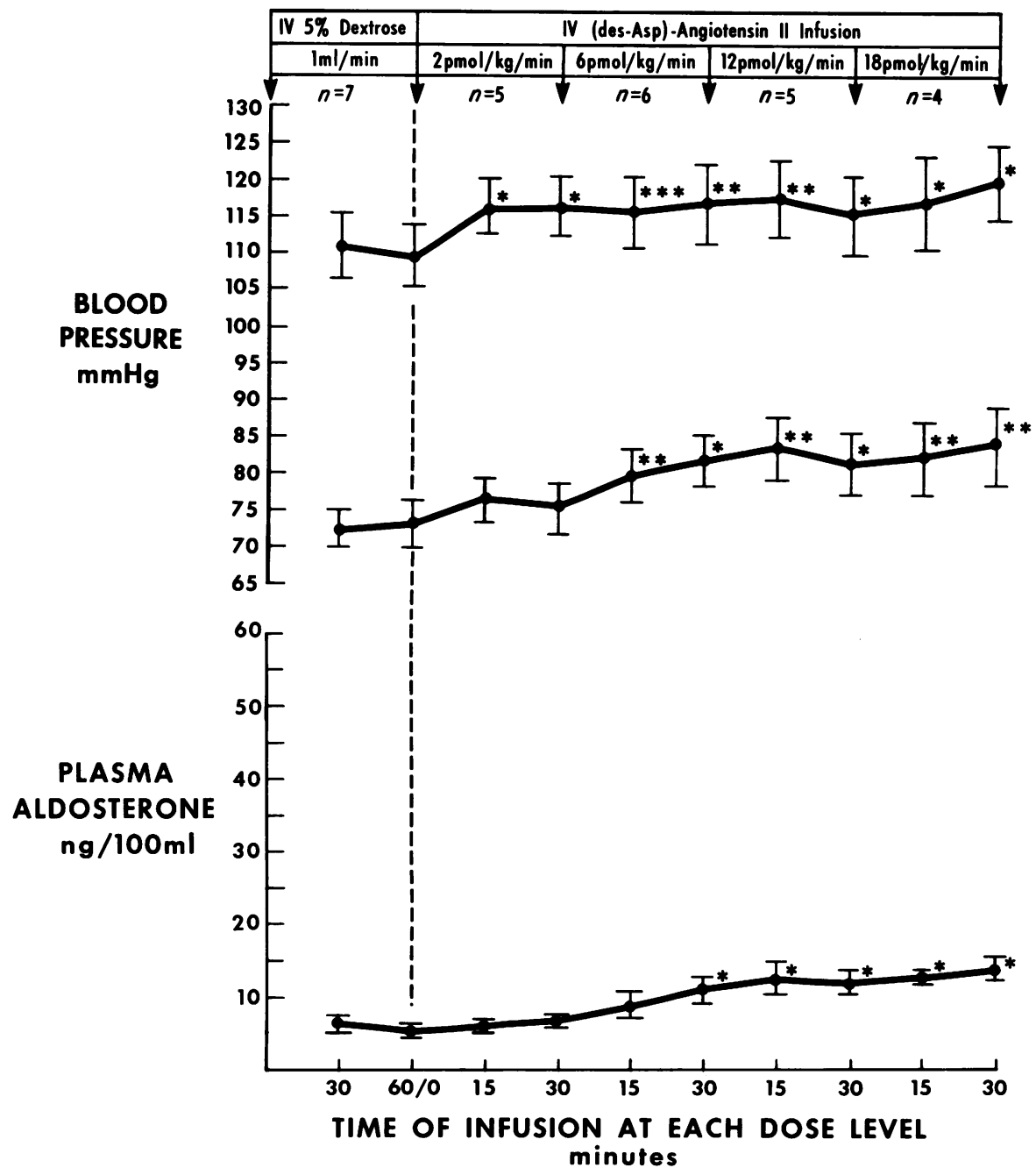

FIGURE 1 Blood pressure and aldosterone responses of subjects to [des-Asp]-A II infusion during normal sodium intake. Each subject received three cumulative doses of heptapeptide. *, values significantly different from zero control values $(P<0.05)$; $\left.{ }^{* *}, P<0.01\right)$; ${ }^{* * *}, P<0.001$. 
creased to $6 \mathrm{pmol} / \mathrm{kg}$ per min at $45 \mathrm{~min}$ of infusion, when the diastolic blood pressure was $79.8 \pm 3.5 \mathrm{~mm} \mathrm{Hg}$ $(P<0.005)$. At $60 \mathrm{~min}$ of infusion, when the subjects still were receiving $6 \mathrm{pmol} / \mathrm{kg}$ per $\mathrm{min}$, the diastolic blood pressure was $82.2 \pm 3.6 \mathrm{~mm} \mathrm{Hg}$; additional increases in the dose of [des-Asp]-A II did not result in a further significant rise in diastolic blood pressure.

Plasma aldosterone concentration was $6.4 \pm 1.1$ $\mathrm{ng} / 100 \mathrm{ml}$ at the end of the second 30 -min control period. There was no significant increase in plasma aldosterone concentration until $60 \mathrm{~min}$ of infusion at a dose of $6 \mathrm{pmol} / \mathrm{kg}$ per min when plasma aldosterone concentration rose to $11.0 \pm 1.8 \mathrm{ng} / 100 \mathrm{ml}(P<0.05)$. Thereafter, plasma aldosterone concentration remained elevated, but did not increase significantly from $11.0 \mathrm{ng} / 100 \mathrm{ml}$ with additional doses of [desAsp]-A II.

Infusion of [des-Asp]-A II did not result in any change in plasma cortisol levels, which were 21.1 $\pm 2.5 \mu \mathrm{g} / 100 \mathrm{ml}$ and $18.6 \pm 2.4 \mu \mathrm{g} / 100 \mathrm{ml}(P=\mathrm{NS})$ at the end of the two consecutive 30 -min control periods, respectively. Plasma potassium concentration was not changed significantly by the administration of [desAsp]-A II.

Plasma renin activity was $1.84 \pm 0.22 \mathrm{ng} / \mathrm{ml}$ per $\mathrm{h}$ at the end of the control period and was decreased to $0.97 \pm 0.19 \mathrm{ng} / \mathrm{ml}$ per $\mathrm{h}(P<0.001)$ at $90 \mathrm{~min}$ of [desAsp]-A II infusion.

Responses to [des-Asp]-A II infusion during low sodium intake (Fig. 2). In the first $30 \mathrm{~min}$ of the control period, blood pressure was $106.0 \pm 4.0 \mathrm{~mm} \mathrm{Hg}$

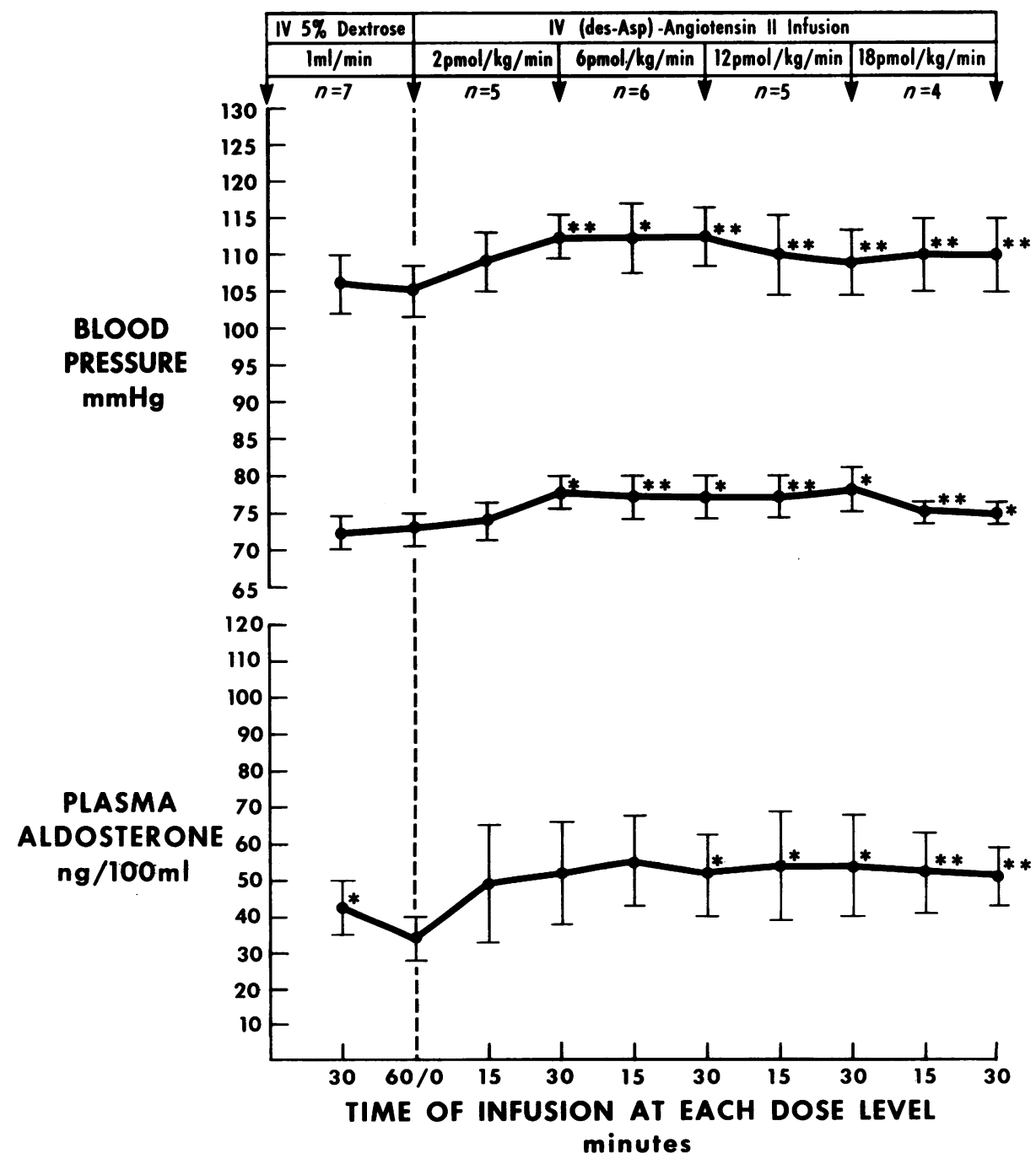

Figure 2 Blood pressure and aldosterone responses of subjects to [des-Asp]-A II infusion during low sodium intake. Each subject received three cumulative doses of heptapeptide. ${ }^{*}$, values significantly different from zero control values $(P<0.05)$; ${ }^{* *}, P<0.01$. 
systolic and $72.4 \pm 2.2 \mathrm{~mm} \mathrm{Hg}$ diastolic, and in the second $30 \mathrm{~min}$ of the control period was unchanged at $105.2 \pm 3.6 \mathrm{~mm} \mathrm{Hg}$ systolic and $73.0 \pm 2.1 \mathrm{~mm} \mathrm{Hg}$ diastolic. Infusion of [des-Asp]-A II again resulted in a rise in systolic blood pressure. This became statistically significant $(112.4 \pm 3.3 \mathrm{~mm} \mathrm{Hg}, P<0.005)$ by 30 $\mathrm{min}$ of the 2-pmol/kg per min dose. Thereafter, with increasing doses and duration of infusion the increase in systolic blood pressure was sustained, but a distinct plateau occurred. Similarly, diastolic blood pressure increased to $77.8 \pm 2.5 \mathrm{~mm} \mathrm{Hg}(P<0.02)$ by the end of infusion of $2 \mathrm{pmol} / \mathrm{kg}$ per min and reached a plateau with time and increasing doses of [desAsp]-A II. In spite of continued infusion with escalating doses of [des-Asp]-A II, neither systolic nor diastolic blood pressure increased significantly above the value obtained during the last $15 \mathrm{~min}$ of the $2-\mathrm{pmol} / \mathrm{kg}$ per min dose. The pattern of an initial rise in mean blood pressure followed by a plateau in response to [des-Asp]-A II was more apparent with sodium restriction than with normal sodium intake. In addition, with low sodium intake, the plateau of the elevated diastolic blood pressure occurred earlier than with the normal sodium diet.

Plasma aldosterone concentration was $42.7 \pm 7.6$ $\mathrm{ng} / 100 \mathrm{ml}$ in the first $30 \mathrm{~min}$ of the control period and fell to $34.4 \pm 6.0 \mathrm{ng} / 100 \mathrm{ml}(P<0.02)$ in the second $30 \mathrm{~min}$ of the control period. With [des-Asp]-A II infusion, plasma aldosterone concentration increased within $15 \mathrm{~min}$ with an infusion of $2 \mathrm{pmol} / \mathrm{kg}$ per min to $48.7 \pm 16.5 \mathrm{ng} / 100 \mathrm{ml}$, and within $30 \mathrm{~min}$ to 52.1 $\pm 14.0 \mathrm{ng} / 100 \mathrm{ml}$, when it reached a plateau. Because of the wide individual variation in control and infusion values, the increase in plasma aldosterone concentration became statistically significant only at $30 \mathrm{~min}$ of the $6-\mathrm{pmol} / \mathrm{kg}$ per min dose, and was statistically different from the control throughout the remainder of the infusion. There was no significant difference between the plasma aldosterone concentration at $30 \mathrm{~min}$ of the $2-\mathrm{pmol} / \mathrm{kg}$ per min dose and any value that was obtained subsequently.

Plasma cortisol concentration was $22.6 \pm 1.6 \mu \mathrm{g} / 100$ $\mathrm{ml}$ at $-30 \mathrm{~min}$ and $19.1 \pm 1.9 \mu \mathrm{g} / 100 \mathrm{ml}(P<0.05)$ at 0 min. During the [des-Asp]-A II infusion, plasma cortisol concentration did not change significantly. Plasma potassium concentration was $3.8 \pm 0.1 \mathrm{meq} / \mathrm{l}$ at $-30 \mathrm{~min}$ and $3.7 \pm 0.1 \mathrm{meq} / \mathrm{l}(P=\mathrm{NS})$ at $0 \mathrm{~min}$ and did not change during the [des-Asp]-A II infusion period.

Plasma renin activity was $8.42 \pm 1.26 \mathrm{ng} / \mathrm{ml}$ per $\mathrm{h}$ in the control period and was decreased to $5.90 \pm 1.32$ $\mathrm{ng} / \mathrm{ml}$ per $\mathrm{h}(P<0.005)$ by $90 \mathrm{~min}$ of [des-Asp]-A II infusion.

Responses to A II infusion during normal sodium intake (Fig. 3). In the first $30 \mathrm{~min}$ of the control period, blood pressure was $109.1 \pm 5.6 \mathrm{~mm} \mathrm{Hg}$ systolic and $69.8 \pm 3.3 \mathrm{~mm} \mathrm{Hg}$ diastolic, and in the second 30 min of the control period was $109.5 \pm 5.0 \mathrm{~mm} \mathrm{Hg}$ systolic and $70.3 \pm 2.9 \mathrm{~mm} \mathrm{Hg}$ diastolic $(P=\mathrm{NS})$. Infusion of A II resulted in a rise in blood pressure at $15 \mathrm{~min}$ of the $2-\mathrm{pmol} / \mathrm{kg}$ per min dose to 117.2 $\pm 2.8 \mathrm{~mm} \mathrm{Hg}(P<0.01)$. In contrast to the blood pressure response to [des-Asp]-A II, A II produced a stepwise increase in both systolic and diastolic blood pressure with time and with each increase in dose up to $6 \mathrm{pmol} / \mathrm{kg}$ per min when an increase of 15.2 $\mathrm{mm} \mathrm{Hg}$ systolic and $20.6 \mathrm{~mm} \mathrm{Hg}$ diastolic from base line was obtained.

Plasma aldosterone concentration was $8.7 \pm 2.5$ $\mathrm{ng} / 100 \mathrm{ml}$ at $-30 \mathrm{~min}$ and $7.0 \pm 2.2 \mathrm{ng} / 100 \mathrm{ml}(P$ $=\mathrm{NS}$ ) at $0 \mathrm{~min}$. A II infusion resulted in an increase in plasma aldosterone to $11.7 \pm 1.7 \mathrm{ng} / 100 \mathrm{ml}$ by $15 \mathrm{~min}$ of the 2-pmol/kg per min dose. Thereafter with time and higher dose of A II, plasma aldosterone concentration increased in a step-wise fashion to 26.8 $\pm 2.0 \mathrm{ng} / 100 \mathrm{ml}(P<0.005)$ with $6 \mathrm{pmol} / \mathrm{kg}$ per min at the end of the infusion.

Plasma cortisol concentration was $20.7 \pm 3.6 \mathrm{ng} / 100$ $\mathrm{ml}$ at $-30 \mathrm{~min}$ and $18.3 \pm 3.4 \mathrm{ng} / 100 \mathrm{ml}(P=\mathrm{NS})$ at 0 min. A II infusion did not alter plasma cortisol levels significantly at any time or dose. Similarly, plasma potassium concentration remained constant during the A II infusion.

Plasma renin activity was $2.06 \pm 0.28 \mathrm{ng} / \mathrm{ml}$ per $\mathrm{h}$ in the control period and was decreased to $1.08 \pm 0.09$ $\mathrm{ng} / \mathrm{ml}$ per $\mathrm{h}(P<0.01)$ by the termination of the A II infusion.

Responses to A II infusion during low sodium intake (Fig. 4). In the control period, blood pressure was $106.1 \pm 4.4 \mathrm{~mm} \mathrm{Hg}$ systolic and $70.8 \pm 2.9$ $\mathrm{mm} \mathrm{Hg}$ diastolic in the first $30 \mathrm{~min}$ and $107.5 \pm 4.3$ $\mathrm{mm} \mathrm{Hg}$ systolic and $70.9 \pm 2.3 \mathrm{~mm} \mathrm{Hg}$ diastolic $(P$ $=\mathrm{NS})$ in the second $30 \mathrm{~min}$. A II administration resulted in a rise in blood pressure to $113.5 \pm 4.8 \mathrm{~mm}$ $\mathrm{Hg}$ systolic and $78.0 \pm 2.7 \mathrm{~mm} \mathrm{Hg}$ diastolic $(P<0.05)$ in the first $15 \mathrm{~min}$ of the 2-pmol/kg per min dose. Thereafter, with increasing time and peptide dose, blood pressure rose in a stepwise fashion. The maximum dose of $6 \mathrm{pmol} / \mathrm{kg}$ per min produced an increase from base line of $12.1 \mathrm{~mm} \mathrm{Hg}$ systolic and $13.3 \mathrm{~mm}$ $\mathrm{Hg}$ diastolic at the end of the infusion.

Plasma aldosterone concentration was $43.3 \pm 7.6$ $\mathrm{ng} / 100 \mathrm{ml}$ at $-30 \mathrm{~min}$ and $42.0 \pm 9.7 \mathrm{ng} / 100 \mathrm{ml}$ $(P=\mathrm{NS})$ at $0 \mathrm{~min}$. A II infusion resulted in a rise in plasma aldosterone concentration to $62.9 \pm 11.0 \mathrm{ng} / 100$ $\mathrm{ml}$ at $15 \mathrm{~min}$ and $70.4 \pm 11.6 \mathrm{ng} / 100 \mathrm{ml}(P<0.02)$ at $30 \mathrm{~min}$ of the $2-\mathrm{pmol} / \mathrm{kg}$ per min infusion. Increasing doses of A II resulted in a dose-dependent increase of plasma aldosterone to $102.2 \pm 15.4 \mathrm{ng} / 100 \mathrm{ml}(P$ $<0.005)$ at the end of the infusion.

Plasma cortisol concentration was $28.6 \pm 2.7 \mu \mathrm{g} / 100$ $\mathrm{ml}$ at $-30 \mathrm{~min}$ and $18.1 \mu \mathrm{g} / 100 \mathrm{ml}(P<0.05)$ at 0 


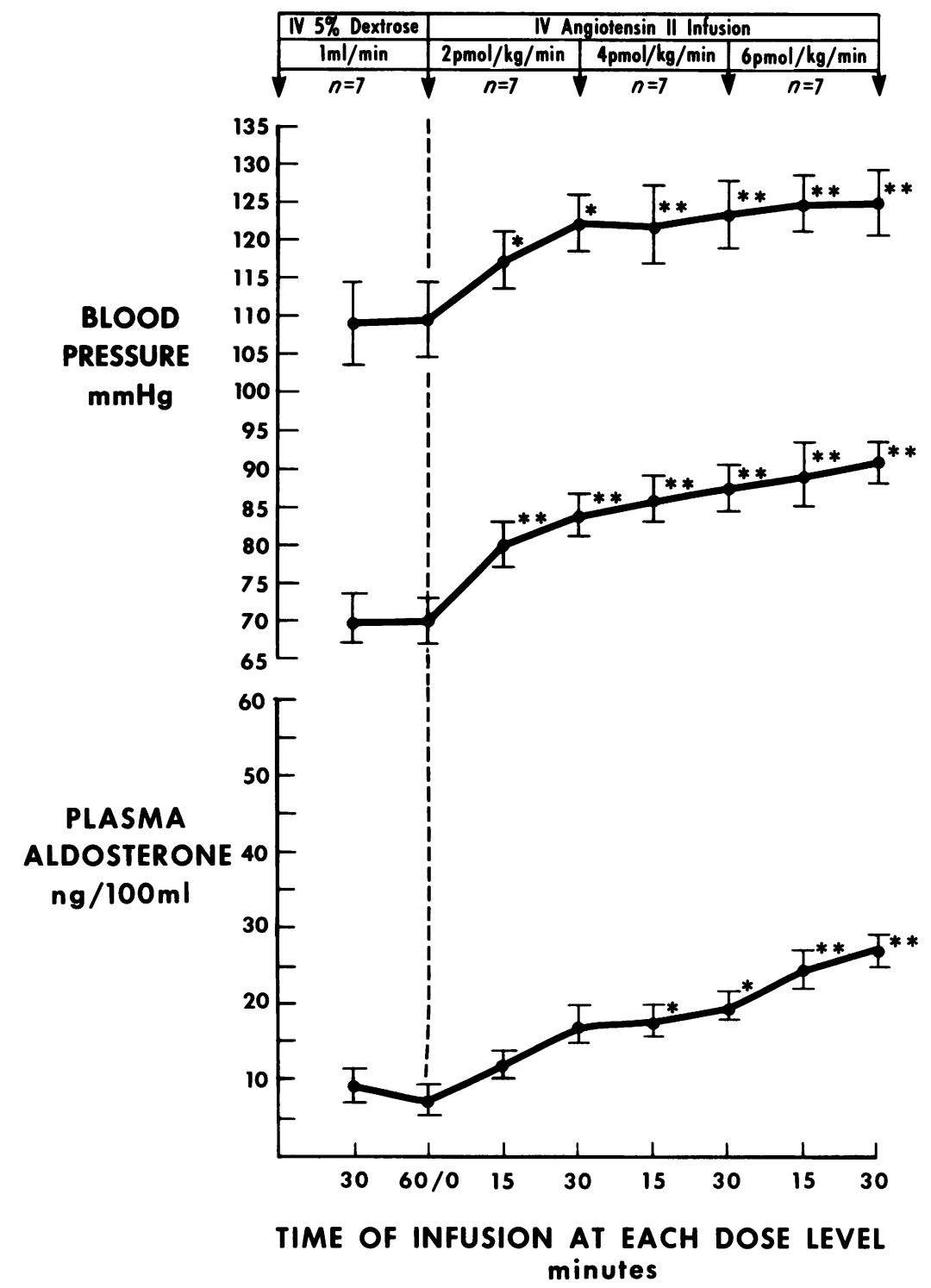

FIGURE 3 Blood pressure and aldosterone responses to A II infusion of subjects during normal sodium intake. Each subject received three cumulative doses of octapeptide. ${ }^{*}$, values significantly different from zero control values $(P<0.05)$; **, $P<0.01$.

min. A II infusion produced no change (from base line) in plasma cortisol or potassium levels in sodiumdepleted subjects.

Plasma renin activity was $9.40 \pm 1.05 \mathrm{ng} / \mathrm{ml}$ per $\mathrm{h}$ in the control period and was decreased to $4.87 \pm 0.68$ $\mathrm{ng} / \mathrm{ml}$ per $\mathrm{h}(P<0.001)$ by the end of the A II infusion.

Comparison of the effects of the angiotensin peptides on blood pressure of subjects during normal and low sodium intake (Fig. 5). The effects of two doses (2 and $6 \mathrm{pmol} / \mathrm{kg}$ per $\mathrm{min}$ ) of each peptide on blood pressure were evaluated. With normal sodium intake [des-Asp]-A II increased mean blood pressure by $1.1 \pm 1.9 \mathrm{~mm} \mathrm{Hg}$ at the $2-\mathrm{pmol} / \mathrm{kg}$ per min dose and by $7.4 \pm 1.7 \mathrm{~mm} \mathrm{Hg}$ at the $6-\mathrm{pmol} / \mathrm{kg}$ per $\mathrm{min}$ dose. In contrast, A II induced an increase in mean blood pressure of $10.3 \pm 1.8 \mathrm{~mm} \mathrm{Hg}$ at $2 \mathrm{pmol} / \mathrm{kg}$ per min and of $20.4 \pm 1.0$ at $6 \mathrm{pmol} / \mathrm{kg}$ per min. At the $2-\mathrm{pmol} / \mathrm{kg}$ per min dose of peptide, [des-Asp]-A II had $11 \%$ of the pressor activity of A II and at the 6-pmol/kg per min dose $36 \%$ of the pressor activity of A II.

With low sodium intake, [des-Asp]-A II increased mean blood pressure by $3.8 \pm 0.3 \mathrm{~mm} \mathrm{Hg}$ at the 2$\mathrm{pmol} / \mathrm{kg}$ per min dose and by $4.1 \pm 0.5 \mathrm{~mm} \mathrm{Hg}$ at the 6-pmol/kg per min dose. By comparison, A II induced 


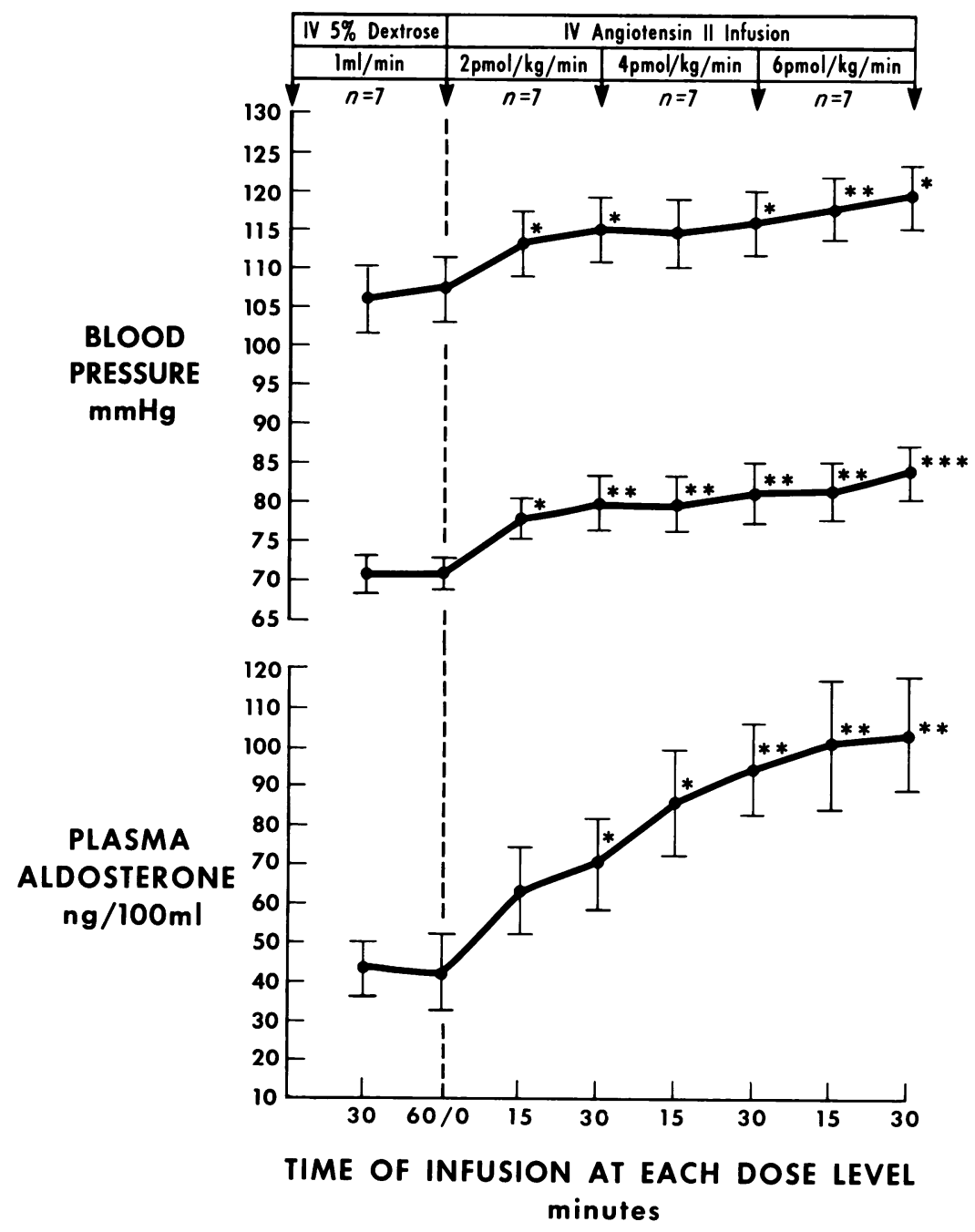

FIGURE 4 Blood pressure and aldosterone responses to A II infusion of subjects during low sodium intake. Each subject received three cumulative doses of octapeptide. ${ }^{*}$, values significantly different from zero control values $(P<0.05)$; ${ }^{* *}, P<0.01$, ***, $P<0.001$.

a pressor response of $6.9 \pm 0.9 \mathrm{~mm} \mathrm{Hg}$ at $2 \mathrm{pmol} / \mathrm{kg}$ per min and of $12.8 \pm 1.6 \mathrm{~mm} \mathrm{Hg}$ at $6 \mathrm{pmol} / \mathrm{kg}$ per $\mathrm{min}$. The dose-response curves at $2 \mathrm{pmol} / \mathrm{kg}$ per min of [des-Asp]-A II had 55\% of the pressor activity of A II, whereas, at the $6-\mathrm{pmol} / \mathrm{kg}$ per min dose, [desAsp]-A II had $32 \%$ of the pressor activity of A II.

At $2 \mathrm{pmol} / \mathrm{kg}$ per min of A II, low sodium intake decreased the pressor response induced by A II from $10.3 \pm 1.9$ to $6.9 \pm 0.9 \mathrm{~mm} \mathrm{Hg}(P<0.05)$. At $6 \mathrm{pmol} / \mathrm{kg}$ per min with low sodium intake, the pressor activity of A II decreased from $20.4 \pm 1.0$ to $12.8 \pm 1.6 \mathrm{~mm} \mathrm{Hg}$ $(P<0.005)$. Low sodium intake also decreased pressor responsiveness to [des-Asp]-A II at the $6-\mathrm{pmol} / \mathrm{kg}$ per min dose level $(P<0.05)$ but did not attenuate pressor responsiveness to the 2 -pmol/kg per min dose of [des-Asp]-A II.
Comparison of the effect of the angiotensin peptides on aldosterone production of subjects during normal and low sodium intake (Fig. 6). With normal sodium intake, [des-Asp]-A II increased plasma aldosterone concentration by $1.5 \pm 1.1 \mathrm{ng} / 100 \mathrm{ml}$ at $2 \mathrm{pmol} / \mathrm{kg}$ per min and $5.8 \pm 2.0 \mathrm{ng} / 100 \mathrm{ml}$ at $6 \mathrm{pmol} / \mathrm{kg}$ per min. A II increased the aldosterone concentration by 8.3 \pm 3.4 and $19.0 \pm 2.6 \mathrm{ng} / 100 \mathrm{ml}$ at 2 and $6 \mathrm{pmol} / \mathrm{kg}$ per min, respectively. The heptapeptide was less efficacious than the octapeptide. At the 2-pmol/kg per min dose, [des-Asp]-A II had $15 \%$ of the steroidogenic activity of A II and at $6 \mathrm{pmol} / \mathrm{kg}$ per min [des-Asp]-A II had $30 \%$ of the aldosterone-stimulating activity of A II.

With low sodium intake, [des-Asp]-A II increased plasma aldosterone concentration by $17.7 \pm 8.6$ and 17.8 


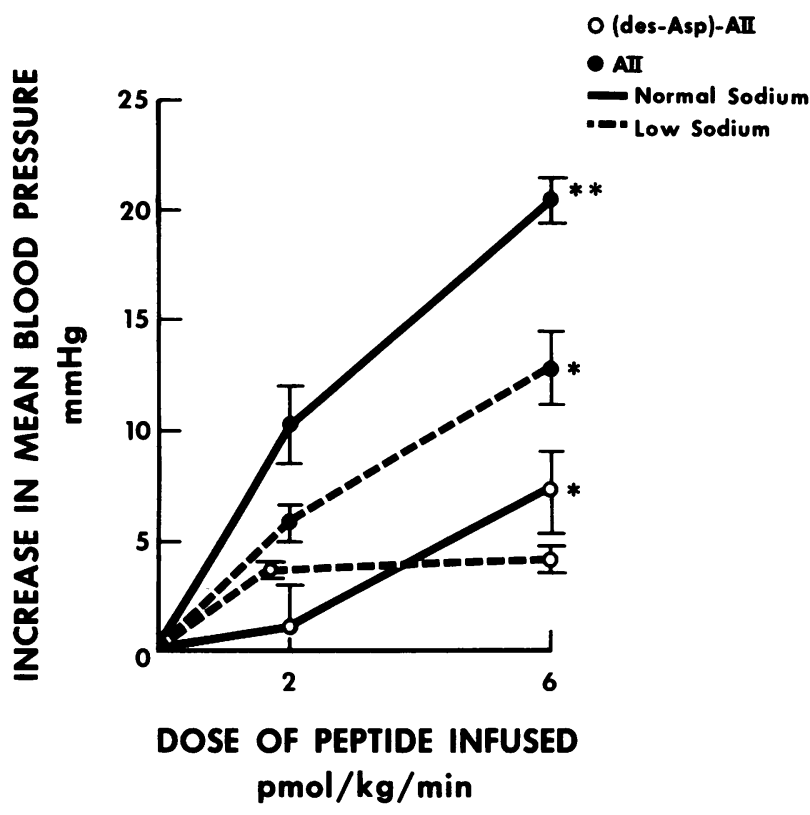

FIGURE 5 Comparison of the effect of the angiotensin peptides on blood pressure of subjects during normal and low sodium intake. ${ }^{*}$, values significantly different from values at $2 \mathrm{pmol} / \mathrm{kg}$ per $\min (P<0.05){ }^{* *}, P<0.01$. During normal sodium intake, [des-Asp]-A II had significantly less pressor activity than A II at 2 and $6 \mathrm{pmol} / \mathrm{kg}$ per $\min (P<0.001)$. During low sodium intake, [des-Asp]-A II also had less pressor activity and A II at each peptide dose $(P<0.01)$.

$\pm 5.1 \mathrm{ng} / 100$ at the 2 - and 6 -pmol $/ \mathrm{kg}$ per min dose levels, respectively. On the other hand, A II produced an increase in the aldosterone level of $31.7 \pm 8.7$ and 63.5 $\pm 9.7 \mathrm{ng} / 100 \mathrm{ml}$ with the two doses, respectively. Low sodium intake increased the increment in aldosterone production induced by [des-Asp]-A II at both dose levels: $0.5 \pm 1.1$ vs. $16.8 \pm 8.6 \mathrm{ng} / 100 \mathrm{ml}(P<0.05)$ at $2 \mathrm{pmol} / \mathrm{kg}$ per min and $5.8 \pm 2.0 \mathrm{vs}$. $15.9 \pm 5.1 \mathrm{ng} / 100$ $\mathrm{ml}(P<0.05)$ at $6 \mathrm{pmol} / \mathrm{kg}$ per min.

Sodium deprivation sensitized the adrenal zona glomerulosa to [des-Asp]-A II more than to A II at the 2-pmol/kg per min dose, when [des-Asp]-A II had $62 \%$ of the aldosterone-stimulating activity of A II. However, there was a plateau in the dose-response curve of the heptapeptide, so that [des-Asp]-A II had only $29 \%$ of the steroidogenic activity of the octapeptide at $6 \mathrm{pmol} / \mathrm{kg}$ per min. Low sodium intake increased the increment in aldosterone production in response to $\mathrm{A}$ II at the 2 -pmol/ $\mathrm{kg}$ per min dose level $(8.3 \pm 3.4$ vs. $29.6 \pm 9.3 \mathrm{ng} / 100 \mathrm{ml}, P<0.05)$ and at the 6 -pmol $/ \mathrm{kg}$ per $\mathrm{min}$ dose level $(19.0 \pm 2.6$ vs. $63.5 \pm 9.7$ $\mathrm{ng} / 100 \mathrm{ml}, P<0.005)$.

\section{Animal in vivo and in vitro studies}

Blood pressure responses to [des-Asp]-A II and A II preparations in nephrectomized rats. In rats main-

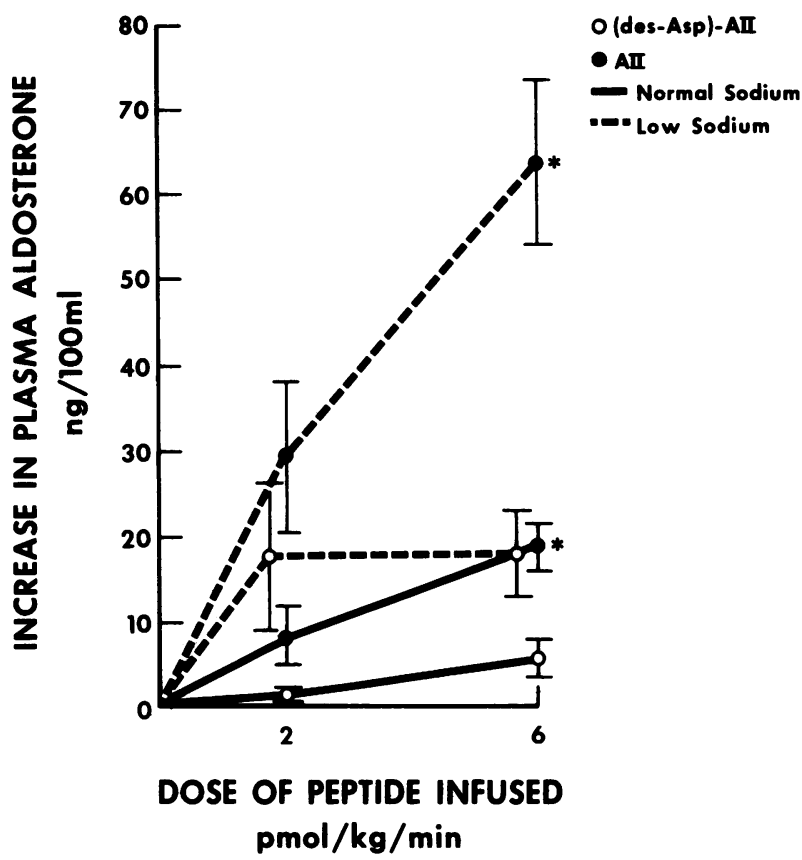

Figure 6 Comparison of the effect of the angiotensin peptides on aldosterone production of subjects during normal and low sodium intake. ${ }^{*}$, values significantly different from values at $2 \mathrm{pmol} / \mathrm{kg}$ per $\min (P<0.05)$. During normal sodium intake, [des-Asp]-A II had significantly less aldosterone-stimulating activity than A II at both peptide doses $(P<0.05)$. During low sodium intake, the difference in aldosterone-stimulating activity in response to the $2-\mathrm{pmol} / \mathrm{kg}$ per min dose of the two peptides was not significantly different, but at $6 \mathrm{pmol} / \mathrm{kg}$ per $\mathrm{min}$, A II had significantly greater activity $(P<0.005)$.

tained on a normal sodium diet, A II from 10 to 200 pmol increased blood pressure from 4 to $50 \mathrm{~mm} \mathrm{Hg}$. [des-Asp]-A II (Schwarz/Mann) and the sterilized preparation of [des-Asp]-A II (Beckman) used in the human studies displayed one-third of the pressor activity relative to A II. A II-induced blood pressure responses were significantly different from [desAsp]-A II responses $(P<0.05)$. There was no significant difference in the blood pressure dose-response curves for [des-Asp]-A II (Schwarz/Mann) and the nonsterilized or sterilized preparations of [des-Asp]A II (Beckman Instruments, Inc.).

Aldosterone responses to [des-Asp]-A II and A II preparations in adrenal cell suspensions. The threshold concentrations of A II and the Schwarz/Mann and Beckman preparations of [des-Asp]-A II in adrenal cell suspensions were identical at $50 \mathrm{pM}$. The maximal steroidogenic responses to [des-Asp]-A II and A II occurred at approximately $10 \mathrm{nM}$, respectively. Responses of adrenal cells to [des-Asp]-A II were greater than those to A II $(P<0.05)$ at $0.1,0.5$, and $1 \mathrm{nM}$ concentrations of the peptides. There was no significant difference in the aldosterone dose-response 
curves for [des-Asp]-A II (Schwarz/Mann) and the nonsterilized or sterilized preparations of [des-Asp]-A II (Beckman).

\section{DISCUSSION}

The present experiments demonstrate that [des-Asp]A II has biologic activity in man. In normal subjects on normal sodium intake, [des-Asp]-A II in the dose range of 2-18 pmol/ $\mathrm{kg}$ per min produced an increment of $30-250 \%$ in plasma aldosterone concentration and a rise in mean arterial pressure of 4.1-10.1 $\mathrm{mm} \mathrm{Hg}$.

In man, as in experimental animals, the present data indicate that [des-Asp]-A II has 20-30\% of the pressor activity of A II. This corresponds with the results of a preliminary investigation by Kono et al. (24), who infused an approximately 10-fold higher single dose of the two peptides in man. We were surprised to find, however, that when cumulative doses were administered [des-Asp]-A II had only $15-20 \%$ of the steroidogenic activity of A II in subjects on normal sodium intake. This relationship of the aldosterone-stimulating activity of the two peptides differs from experimental animal studies (5-9) and from the results of Kono and co-workers, who found that [des-Asp]-A II was approximately equipotent with A II in the human adrenal cortex. With similar baseline plasma aldosterone concentrations in Kono's and our study, we achieved about the same increment in plasma aldosterone with $18 \mathrm{pmol} / \mathrm{kg}$ per min of [des-Asp]-A II as Kono et al. did with the administration of $22 \mathrm{pmol} / \mathrm{kg}$ per min. However, Kono used a much larger dose of A II ( $20 \mathrm{pmol} / \mathrm{kg}$ per min) than we did, producing a striking pressor effect which markedly exceeded our preset upper limit for the rise in blood pressure. His single sampling for plasma aldosterone was at $30 \mathrm{~min}$, which may have been too early to observe maximum steroidogenesis (25). Inasmuch as we achieved about the same increase in aldosterone with only $6 \mathrm{pmol} / \mathrm{kg}$ per min of A II by $60 \mathrm{~min}$ of infusion as Kono obtained with $22 \mathrm{pmol} / \mathrm{kg}$ per min for $30 \mathrm{~min}$, the most likely explanation for the discrepancy in results between the two studies is that aldosterone production in the response to A II was still increasing at the time of Kono's sampling but may have risen close to peak at that time with [des-Asp]-A II. Other factors that may also have contributed to the difference in results include differences in subjects or their ages, differences in sodium balance, which is not stated for Kono's subjects, differences in the methods of measuring aldosterone, or differences in the chemical purity of the heptapeptide preparation. This disparity between in vivo human and in vitro animal tests of relative potency in the adrenal zona glomerulosa which we have demonstrated may be a consequence of species differences or of more rapid in vivo degradation of [des-Asp]-A II than A II (26). The results suggest that in man under conditions of normal sodium balance, [des-Asp]-A II possesses appreciable aldosterone-stimulating activity, but less than that observed in other species such as the rat or rabbit. Further studies, including infusion of higher doses of both peptides initially and for a longer period of time, and comparison of the inhibitory effects of hepta- and octapeptide analogues on the cardiovascular system and adrenal cortex, will be required to amplify the results of this study.

Dietary sodium deprivation in man is followed by enhanced activity of the renin-angiotensin-aldosterone system as manifested by increased plasma renin activity and aldosterone secretion and excretion $(1,3,27)$. In the present study, as reported by others $(25,27)$, vascular sensitivity to A II decreased significantly when sodium intake was restricted. The pressor response to infused A II in subjects on low sodium intake was reduced to $62-68 \%$ of the pressor response obtained on normal sodium intake. In contrast, however, low sodium intake increased the pressor activity of [des-Asp]-A II at the initial and lowest dose of $2 \mathrm{pmol} / \mathrm{kg}$ per min. However, with progressively higher doses of [des-Asp]-A II, we observed a progressive and significant decrease in vascular sensitivity during sodium depletion. At $18 \mathrm{pmol} / \mathrm{kg}$ per min of [des-Asp]-A II, the pressor response was reduced to $29 \%$ of the response in subjects on a normal sodium diet. These results, with the exception of the lowest dose, agree with previous descriptions of vascular responsiveness to [des-Asp]-A II in the presence of sodium depletion in the rat (16).

Recent studies suggest that the octapeptide and heptapeptide differ somewhat in their selectivity for vascular smooth muscle and adrenal cortex. Aldosterone biosynthesis induced by A II or [des-Asp]-A II is inhibited more readily by the heptapeptide analogue, [des-Asp ${ }^{1}$, Ile $\left.^{8}\right]-A$ II, than by the octapeptide analogue, [Sar $\left.{ }^{1}, \mathrm{Ile}^{8}\right]-\mathrm{A}$ II in vitro and in vivo (28). The octapeptide analogue, however, effectively inhibits vascular smooth muscle and blood pressure responses to both peptides $(16,29)$. In the present study, [des-Asp]-A II and A II administration under normal conditions of sodium balance resulted in predominance of vascular smooth muscle and adrenal cortical responses to the octapeptide. These results differ from those of animal studies showing that the heptapeptide displays greater affinity for the adrenal zona glomerulosa and, thus, for stimulation of aldosterone secretion. During sodium restriction in man, however, the adrenal cortex was sensitized more to the action of the heptapeptide than to the octapeptide at the initial dose of $2 \mathrm{pmol} / \mathrm{kg}$ per min, resulting 
in approximately equivalent potency of the two peptides. These results are consistent with the hypothesis derived from animal studies that [des-Asp]-A II may mediate, at least in part, the aldosterone response to sodium restriction.

In our study, both A II and [des-Asp]-A II produced equivalent suppression of renin release in sodium-repleted and sodium-depleted normal subjects. This confirms the results of Freeman et al. $(13,30)$ in the dog and Steele and colleagues (7) in the rabbit. The mechanism of the inhibitory effect on renin secretion is not understood completely, but the data are consistent with feedback inhibition of the peptide at the juxtaglomerular apparatus $(31,32)$. A renal hemodynamic mechanism also is possible, but the marked differences in renal vasoconstrictor effects of the octapeptide and heptapeptide in the rabbit, $\mathrm{dog}$, and isolated, perfused rat kidney (33) do not account for equivalent suppression of renin secretion by the two peptides. As well, it is unlikely that renin suppression is due to an effect of the peptides on sodium delivery to the distal tubule or sodium transport in the ascending limb of the loop of Henle because the degree of renin suppression is independent of changes in renal sodium excretion $(7,30)$. Because we did not assess renal hemodynamics and sodium excretion in response to [des-Asp]-A II, the contribution of these mechanisms to the observed renin suppression in man remains to be clarified.

The most striking finding of the present study is the difference in dose-response curves to A II and [des-Asp]-A II in man. In the sodium-depleted subjects, increasing doses of A II produce a stepwise increase in blood pressure and aldosterone production. The initial dose of [des-Asp]-A II results in a rise in blood pressure and aldosterone production. However, with progressively higher doses of [des-Asp]-A II, a plateau of blood pressure and aldosterone production occurs. A similar, less dramatic difference in doseresponse curves with the two peptides also was observed in the sodium-repleted subjects. The doseresponse curves are not parallel and although no maximum was established for A II, [des-Asp]-A II was clearly less efficacious. This difference in doseresponse curves to A II and [des-Asp]-A II both in vascular smooth muscle and adrenal cortex suggests that the receptors for A II and [des-Asp]-A II in these tissues may be either anatomically or functionally different.

The in vivo difference in dose-response curves to A II and [des-Asp]-A II in man is consistent with dose-response relationships in certain in vitro preparations. For example, in the normal cat papillary muscle, the dose-response curves of [des-Asp $\left.{ }^{1}, \mathrm{Val}^{5}\right]-\mathrm{A}$ II and [des-Asp ${ }^{1}$, Ile $^{5}$ ]-A II for tension $(\mathrm{T})$ and $\mathrm{d} T / \mathrm{d} t$ are flat compared with the dose-response curves for A II (34). Recent studies in rat uterine smooth muscle also have shown nonparallel dose-response curves for A II and [des-Asp]-A II (20). The fact that [desAsp $^{1}$, Ile $\left.^{8}\right]-A$ II and $\left[\mathrm{Sar}^{1}, \mathrm{Ile}^{8}\right]-A$ II displayed different $\mathrm{PA}_{2}$ values (negative log of the molar concentration of the antagonist which requires twice the concentration of agonist to induce the same response as in its absence) against A II than against the heptapeptide was taken as evidence that A II and the heptapeptide act upon different uterine receptors. This conclusion was supported by the absence of complete cross-tachyphylaxis: tachyphylaxis to A II blocked the response to the heptapeptide but tachyphylaxis to the heptapeptide did not attenuate the response to A II. However, another possible explanation for these findings is conversion of A II to heptapeptide by tissue aminopeptidases resulting in blockade of further stimulation by exogenous heptapeptide. Other evidence also has accumulated that A II and [des-Asp]-A II may act via different receptors in some tissues. Cycloheximide or aminoglutethimide, in concentrations that totally block ACTH- and A II-induced steroidogenesis in the rabbit adrenal cortex, have no appreciable effect upon [des-Asp]-A II-induced aldosterone biosynthesis (M. J. Peach, unpublished observations). However, A II and [des-Asp]-A II have been shown to act at the same receptor in the renal vascular bed of the dog (35). The availability of two angiotensin agonists, [des-Asp]-A II and A II, clearly demonstrating different blood pressure and steroidogenic dose-response relationships, offers a new approach to clarify whether or not a family of angiotensin receptors exists in man. Cross-tachyphylaxis experiments and comparison of the degree of inhibition of A II and [des-Asp]-A II by their respective analogues, when available, should provide fruitful avenues for future investigation.

\section{ACKNOWLEDGMENTS}

The authors are pleased to acknowledge the excellent technical assistance of Ms. Elizabeth M. Ortt and the help of Mrs. Julie Mawyer in the preparation of the manuscript. We are indebted to Dr. John Ackerly for review of the manuscript.

This work is supported by U. S. Public Health Service General Clinical Research Center grant RR-847 and in part by research grant AM-17523.

\section{REFERENCES}

1. Laragh, J. H., M. Angers, W. G. Kelly, and S. Lieberman. 1960. The effect of epinephrine, norepinephrine, angiotensin II, and others on the secretory rate of aldosterone in man. J.A.M.A. (J. Am. Med. Assoc.). 174: 234-240.

2. Ames, R. P., A. J. Borkowski, A. M. Sincinski, and J. H. Laragh. 1965. Prolonged infusions of angiotensin II and norepinephrine and blood pressure, electrolyte balance, aldosterone and cortisol secretion in normal man and in cirrhosis with ascites. J. Clin. Invest. 44: 1171-1186. 
3. Laragh, J. H., L. Baer, H. R. Brunner, F. R. Bühler, J. E. Sealey, and E. D. Vaughan, Jr. 1972. Renin, angiotensin, aldosterone system in pathogenesis and management of hypertensive vascular disease. Am. J. Med. 52: 633-652.

4. Ledingham, J. G., and W. P. Leary. 1974. Catabolism of angiotensin II. In Angiotensin. I. H. Page and F. M. Bumpus, editors. Springer-Verlag New York Inc., N. Y. 111-125.

5. Blair-West, J. R., J. P. Coghlan, D. A. Denton, J. W. Funder, B. A. Scoggins, and R. D. Wright. 1971. Effect of the heptapeptide (2-8) and hexapeptide (3-8) fragments of angiotensin II on aldosterone secretion. $J$. Clin. Endocrinol. Metab. 32: 575-578.

6. Campbell, W. B., S. N. Brooks, and W. A. Pettinger. 1974. Angiotensin II- and angiotensin III-induced aldosterone release in vivo in the rat. Science (Wash. D. C.). 184: 994-996.

7. Steele, J. H., A. J. Neusy, and J. Lowenstein. 1976. The effect of [des-asp ${ }^{1}$ ]-angiotensin II on blood pressure, plasma aldosterone concentration and plasma renin activityin the rabbit. Circ. Res. 38(Suppl. 2): 113-116.

8. Bravo, E. L., M. C. Khosla, and F. M. Bumpus. 1976. The role of angiotensins in aldosterone production. Circ. Res. 24(Suppl. 2): 104-107.

9. Peach, M. J., and A. T. Chiu. 1974. Stimulation and inhibition of aldosterone biosynthesis in vitro by angiotensin II and analogs. Circ. Res. 34 and 35(Suppl. 1): 7-13.

10. Goodfriend, T. L., and M. J. Peach. 1975. Angiotensin III: [des-aspartic acid $^{1}$ ]-angiotensin II: evidence and speculation for its role as an important agonist in the renin-angiotensin system. Circ. Res. 36 and 37(Suppl. 1): 138-148.

11. Bumpus, F. M., P. A. Khairallah, K. Arakawa, I. H. Page, and R. R. Smeby. 1961. The relationship of structure to pressor and oxytoxic action of isoleucine-5-angiotensin octapeptide and various analogs. Biochim. Biophys. Acta. 46: $38-44$.

12. Khosla, M. D., R. R. Smeby, and F. M. Bumpus. 1974. Structure-activity relationship in angiotensin II analogs. In Angiotensin. I. H. Page and F. M. Bumpus, editors. Springer-Verlag New York Inc., N. Y. 126-161.

13. Freeman, R. H., J. O. Davis, and T. E. Lohmeier. 1975. Des-asp ${ }^{1}$-angiotensin II: possible intrarenal role in homeostasis in the dog. Circ. Res. 37: 30-34.

14. Semple, P. F., and J. J. Morton. 1976. Angiotensin II and angiotensin III in rat blood. Circ. Res. 24(Suppl. 2): $122-126$

15. Semple, P. F., A. S. Boyd, P. M. Dawes, and J. J. Morton. 1976. Angiotensin II and its heptapeptide (2-8), hexapeptide (3-8) and pentapeptide (4-8) metabolites in arterial and venous blood of man. Circ. Res. 39: 671-677.

16. Peach, M. H., C. A. Sarstedt, and E. D. Vaughan, Jr. 1976. Changes in cardiovascular and adrenal cortical responses to angiotensin III induced by sodium deprivation in the rat. Circ. Res. 38(Suppl. 2): 117-121.

17. Brecher, P. I., H. Y. Pyum, and A. V. Chobanian. 1974. Studies on the angiotensin II receptor in the zona glomerulosa of the rat adrenal gland. Endocrinology. 95: 1026-1033.

18. Chiu, A. T., and M. J. Peach. 1974. Inhibition of induced aldosterone biosynthesis with a specific antagonist of angiotensin II. Proc. Natl. Acad. Sci. U. S. A. 71: $341-344$.
19. Peach, M. J., and J. A. Ackerly. 1976. Angiotensin antagonists and the adrenal cortex and medulla. Fed. Proc. 35: 2502-2507.

20. Moore, A. F., M. M. Hall, and P. A. Khairallah. 1976 A comparison of the effects of angiotensin II and heptapeptide on smooth muscle (vascular and uterine). Eur.J. Pharmacol. 39: 101-107.

21. Bühler, F. R., J. E. Sealey, and J. H. Laragh. 1974. Radioimmunoassay of plasma aldosterone. In Hypertension Manual. J. H. Laragh, editor. Dun-Donnelley. New York. 655-672.

22. Sealey, J. E., J. H. Laragh, J. Gertew-Banes, and R. M. Aceto. 1974. The measurement of plasma renin activity in man. In Hypertension Manual. J. H. Laragh, editor. Dun-Donnelley, New York. 621-640.

23. Mattingly, D. 1962. A simple fluorimetric method for estimation of free 11-hydroxycorticoids in human plasma. J. Clin. Pathol. (Lond.). 15: 374-379.

24. Kono, T., F. Oseko, S. Shimpo, M. Nanno, and J. Endo. 1975. Biological activity of des-asp ${ }^{1}$-angiotensin II (angiotensin III) in man. J. Clin. Endocrinol. Metab. 41: 1174-1177.

25. Oelkers, W., J. J. Brown, R. Fraser, A. F. Lever, J. J. Morton, and J. I. S. Robertson. 1974. Sensitization of the adrenal cortex to angiotensin II in sodium-deplete man. Circ. Res. 34: 69-77.

26. DeGraaf, J. S., A. C. A. Jansen, and D. E. T. Kerling. 1971. Studies on polypeptides. XII. Myotropic activities of some des-asp ${ }^{1}-\left(\right.$ ile $\left.^{5}\right)$-angiotensin analogs: data and a working hypothesis on the contribution of the arginine residue to activity. Rec. Trav. Chim. Pays-Bas. 90: 301308.

27. Hollenberg, N. K., W. R. Chenitz, D. F. Adams, and G. H. Williams. 1974. Reciprocal influence of salt intake on adrenal glomerulosa and renal vascular responses to angiotensin II in normal man. J. Clin. Invest. 54: 34-42.

28. Sarstedt, C. A., E. D. Vaughan, Jr., and M. J. Peach. 1975. Selective inhibition by des-1-asp-8-ile-angiotensin II of the steroidogenic response to restricted sodium intake in the rat. Circ. Res. 37: 350-358.

29. Bravo, E. L., M. C. Khosla, and F. M. Bumpus. 1975. Action of [1-des(aspartic acid),8-isoleucine] angiotensin II upon the pressor and steroidogenic activity of angiotensin II. J. Clin. Endocrinol. Metab. 40: 530-533.

30. Freeman, R. M., J. O. Davis, T. E. Lohmeier, and W. S. Spielman. 1976. Evidence that [des-asp $\left.{ }^{1}\right]$-angiotensin II mediates the renin-angiotensin response. Circ. Res. 38 (Suppl. 2): 99-103.

31. Bunag, R. D., I. H. Page, and J. W. McCubbin. 1967. Inhibition of renin release by vasopressin and angiotensin. Cardiovasc. Res. 1: 67-73.

32. Shade, R. E., J. O. Davis, J. A. Johnson, R. W. Gatshall, and W. S. Spielman. 1973. Mechanism of action of angiotensin II and antidiuretic hormone on renin secretion. Am. J. Physiol. 224: 926-929.

33. Van Dongen, R., W. S. Peart, and G. W. Boyd. 1974 Effect of angiotensin II and its nonpressor derivatives on renin secretion. Am. J. Physiol. 226: 227-232.

34. Kent, K. M., T. L. Goodfriend, Z. T. McCallum, P. J. Dempsey, and T. Cooper. 1972. Inotropic agents in hypoxic cat myocardium: depression and potentiation. Circ. Res. 30: 196-204.

35. Tau, K. J., W. J. H. Caldicott, and N. K. Hollenberg. 1977. Angiotensin antagonists with increased specificity for the renal vasculature. J. Clin. Invest. 59: 528-535. 